International Journal of Agriculture, Environment and Bioresearch

Vol. 5, No. 06; 2020

ISSN: $2456-8643$

\title{
EFFECTS OF MICROCREDIT ON THE LIVING CONDITIONS OF WOMEN IN THE 8TH ARRONDISSEMENT OF COTONOU: AN EMPIRICAL ANALYSIS OF SOCIOECONOMIC REFERENTS
}

\author{
Ilyass SINA D. \\ National University of Agriculture \\ Abdoulaye BENON \\ University of Abomey-Calavi \\ https://doi.org/10.35410/IJAEB.2020.5576
}

\begin{abstract}
Designed originally torespond to an economic and social problem, the microcredit failed to satisfy all expectations regarding its impact on the living conditions of populations. The present research mainly aims to study the social economic effects of the microcredit towomen in the 8th district of Cotonou. The sample of study was drawn at a double degree. A first degree of a geographic scope, retained (06) of the (08) neighborhoods comprised in the District. Stratified second degree and accidental choice were used to choose identified beneficiariesOn the one hand, the results reveal that women as mothers, widowed, out of school, live in conditions of social and economic precariousness. On the other hand, access to microcredit enables them to improve significantly their socio-economic situation. However, the complexity of administrative procedures, guarantees and interest rate as well as the smallness of the credit mortgage the initiatives and constitute constraints to women.
\end{abstract}

Keywords: Microcredit, Poverty, Woman, Living conditions, Cotonou.

\section{INTRODUCTION}

The situation of social vulnerability of women is a subject that rests the debate on the social status of women and the issue of the development of developing societies. The feminization of poverty has become of concern because of the discourse on the involvement of women in development processes (UNDP, 1991, page number?). Numerous studies carried out by the United Nations Development Program (UNDP) show that "poverty has a woman's face" (UNDP 2011, p.38). Thus, "gender has become an essential and consensual entry point for new poverty reduction strategies. This notorious transformation from the mid-1990s was even more marked with the formulation of the Millennium Development Goals (MDGs) at the dawn of the 21st century "(Prévost et al., 2011, p. 38). The observation of the feminization of poverty has given rise to various strategies of struggle, including the one that is increasingly widespread today is microcredit. In order to fight poverty, which affects women more, international development financial institutions such as the World Bank (WB) and the International Monetary Fund (IMF), as well as the governments of developing countries have placed emphasis on microcredit for the 
Vol. 5, No. 06; 2020

ISSN: $2456-8643$

benefit of women. This gender-based development approach consists not only of financing women but also of giving them more power in the society where they were once subjected.

In Benin, microcredit occupies a prominent place in poverty reduction action programs and involves several actors. Since 2007, the Government has launched a vast microcredit program for the poorest (MCPP), an initiative of which women are the main beneficiaries. The underlying assumption of the said program is that by promoting the poor's access to low-level funding, they are given the opportunity to undertake income-generating activities and access basic social services in order to help them reduce their level of poverty and hence that of their families. An amount of around 30,000 CFA francs is granted to the most "destitute" women to undertake an income-generating activity. This program was designed because of socioeconomic data and especially the realities that the population is experiencing. In fact, the average economic growth rate was around 3.3\% over the period from 2002 to 2005; an economic situation which still proved to be very weak to improve the living conditions of the populations (OSC, 2010, p.19). The Human Development Index (HDI) also remained very low compared to the norm, an estimate of 0.47 in 2006 versus 0.743 the global average (OSC, 2010, p.26). In addition, there are difficulties in accessing credit by vulnerable populations in general and in particular by women from local microfinance structures without any guarantee. Thus, the poorest households always remain in precariousness. From these situations, the government of Benin, at the request of the actors of the system, instituted the National Microfinance Fund, created by Decree No. 301-206 of the July 27, 2006. This initiative aimed to contribute to the achievement of the Millennium Development Goals (MDGs) through the National Growth Strategy for Poverty Reduction (SCRP). This measure was to facilitate greater access of the poorest to credit without other forms of material guarantee other than joint surety, with the Micro Credit to the Poorest (MCPP) program.

It is clear that despite these multiple efforts, the precarious situation of women has not changed, indeed, although this is a program in which women are the main beneficiaries, after ten years of implementation, it is observed that $40 \%$ did not experience a significant improvement in their living conditions. Out of 5 women, 4 still complain about their living conditions, both in rural and urban areas. The populations continue to suffer the throes of poverty with the poverty index increasing, from $36.2 \%$ in 2011 to $40.1 \%$ in 2015 (EMICOV and INSAE, 2015). In other words, two out of five Beninese are unable to meet their basic needs. In certain localities of the Cotonou commune, this situation is all the more observable. In the 8th arrondissement, the findings show that: women's income is not secure; children continue to be out of school due to insufficient financial means; women abandon their small businesses because of uncovered income.

This situation cannot leave the researcher indifferent. In light of this, can we say that the use of microcredit has helped improve the living conditions of women, especially in the case of the 8th arrondissement of Cotonou? The question deserves to be asked in order to know in particular how access to microcredit can contribute to the fight against poverty at the level of women, specifically in the 8th arrondissement of Cotonou. The basic hypothesis postulates that the demand for microcredit by women in the 8th arrondissement of Cotonou is rooted in their socioeconomic conditions. The research objective is to bring out the effects of microcredits on the living conditions of women beneficiaries in the 8th arrondissement of Cotonou.

The concept of poverty is a polysemous concept because of the different contexts in which it can be housed. It can be defined not only in terms of deprivation of material goods, but also, in terms 
of cultural goods essential to a person's life and capable of enabling him to develop, to be a full member of society (Demba Diallo, 2014). Since 1978, Tévoédjrè has shown the paradox of this concept by saying that poverty is rather the "wealth of peoples", on the basis that by pooling our scarce resources we can optimize to produce more (Tévoédjrè , 1978, p.208). Credit, for its part, is generally defined as the mechanism by which a debtor obtains goods or money from a creditor in exchange for the promise of a deferred payment of the counterpart, increased by interest (Dictionary of Economy and Social Sciences, 1989 p.120). Credit therefore makes it possible to have a good produced by others before having produced the equivalent oneself.Microcredit is in a way a variant of credit that takes place not only in banks but also and especially in microfinance structures such as non-governmental organizations (NGOs) which manage microcredit, associations, local savings and credit banks, tontines etc. Microfinance is often practiced by formal, structured institutions whose activities are officially recognized by the State. As microfinance institutions in Benin, there are, for example, the NGO PEBCO Bethesda, CLCAM, PADME, Vital Finance, but also the FECECAM or Alidé microfinance network... which generally grant loans ranging from 20,000 to 5,000. 000 CFA francs to the populations. Thus, in the implementation of the MCPP program, these microfinance institutions played an important role with the interface of the State providing the mechanism and financial resources for the women beneficiaries.

Research on microcredit would have been integrated into the microfinance system around 1983 with the Grameen Bank. However, their experiences in sub-Saharan Africa, Cameroon and Burkina-Faso date back to the 1960s. According to the results of research conducted by Hofmann and Kamala (2003), microcredit is an instrument of empowerment for poor women and above all makes it possible to change the socio-professional status of women by giving them the image of a woman entrepreneur. Pal (2009) has shown in his study that microcredit enables beneficiaries to be self-sufficient, by undertaking income-generating activities, which income enables them to invest more in their businesses and save. However, Acclassato (2008) points out that interest rate ceilings can act as a drag on credit contractors.

\section{THEORETICAL FRAMEWORK OF THE STUDY}

Microcredit is one of the poverty reduction strategies initiated by the Beninese government in collaboration with actors from microfinance institutions in 2007. The study took the subject of microcredit from a sociological angle, without ignoring the economic dimensions. This implies that the economic facts are rooted in the social constructions made of credit by the actors themselves. Microcredit then appears as a hybrid phenomenon, caught in a market logic, but with specific and sociological springs that will have to be identified, described and made explicit in a complex dynamic of innovation faced with the challenge of fight against poverty in urban areas such as that of the 8th district of Cotonou. The analysis model retained is therefore based on the theory of "embeddedness", that is to say of "the economy caught in the net by socio-cultural realities" developed by Polanyi (1983) and updated by Olivier. de Sardan (1995) in his work. Microfinance is then analyzed here through the microcredit program for the poorest in the 8th arrondissement of Cotonou in a perspective of innovation leading to social change characterized by complex dynamics of actors, issues and challenges for the fight against poverty in urban areas. The analysis of the results resulting from all these dynamics fits into the sociological context and that of the socio-anthropology of development. 


\section{METHODS AND MATERIALS}

Studying the effects of microcredit on beneficiaries requires a particular methodological approach to identify beneficiaries and better to question them. Thus, the methodological approach adopted is essentially qualitative with the use of some quantitative data. Qualitative data was collected from women beneficiaries of microcredit to obtain their point of view on the advantages and constraints linked to credit. Quantitative data was obtained from microcredit structures, in particular statistics on the system put in place.

The study population is that of the 8th arrondissement of Cotonou. The survey unit is represented by a household in which the woman received microcredit from Micro Finance Institutions (MFIs) in the 8th arrondissement of Cotonou. It is therefore :

Women beneficiaries of loans in microfinance institutions in the 8th arrondissement;

Agents of microfinance institutions;

Local authorities as well as local elders;

Members of beneficiary households.

The typical sampling technique or reasoned choice made it possible to interview the agents of microfinance structures and local authorities. The snowball technique was used to identify beneficiaries in the various districts of the arrondissement. They are: Agbondjèdo, Agontinkon, Houénoussou, Tonato, Houéhoun, Médédjro.

A total of ninety-three (93) informants were approached for individual interviews and five focus group discussions on the procedures for obtaining credit, the management of credit and the effects on the daily life of households.

To collect the data, two techniques were favored, direct observation and semi-structured interview. The main tools that go with these techniques respectively are the observation grid and the interview guide.The observation grid took into account the observable aspects of the living environment of said beneficiaries, namely the types of housing and the living conditions of the households visited. The interview guide used is made up of topics such as the conditions of access to loans from the MCPP program, the profile of the women beneficiaries encountered, the known constraints in the development of the loans contracted, the interest of the loan on the taking into care of the family, education, health, household food, etc.

The information collected was processed and analyzed manually; this made it possible to bring out the various trends concerning the concerns raised.

\section{RESULTS}

\subsection{Socioeconomic characteristics of credit beneficiaries and implications}

The data collection made it possible to take stock of the women beneficiaries. Their marital status and occupation before the implementation of the MCPP program are highlighted here. 
Table 1: Distribution of beneficiaries according to marital status

\begin{tabular}{|l|l|r|r|r|r|}
\hline \multicolumn{7}{|c|}{ Marital status } \\
\hline Modalities & Workforce & Percentage & $\begin{array}{c}\text { Valid } \\
\text { percentage }\end{array}$ & $\begin{array}{c}\text { Cumulative } \\
\text { percentage }\end{array}$ \\
\hline \multirow{5}{*}{ Valid } & Married & 19 & 15,4 & 15,4 & 15,4 \\
\cline { 2 - 6 } & Concubinage & 6 & 4,9 & 4,9 & 20,3 \\
\cline { 2 - 6 } & Divorcee & 25 & 20,3 & 20,3 & 40,7 \\
\cline { 2 - 6 } & Widow & 66 & 53,7 & 53,7 & 94,3 \\
\cline { 2 - 6 } & Single & 7 & 5,7 & 5,7 & 100,0 \\
\cline { 2 - 6 } & Total & 123 & 100,0 & 100,0 & \\
\hline
\end{tabular}

Source: Study data, 2018

Table I shows that the more vulnerable the marital status of women, the more they are obliged to undertake an income-generating activity. Thus, widowed, separated or divorced women express the request for obtaining credit; or respectively a percentage of $66 \%$ and $25 \%$ of the women surveyed. However, there is a significant proportion of women in a couple or married (15.4\%). This implies that the more the burden of the household falls on the woman, the more she looks for an activity to take care of her household.

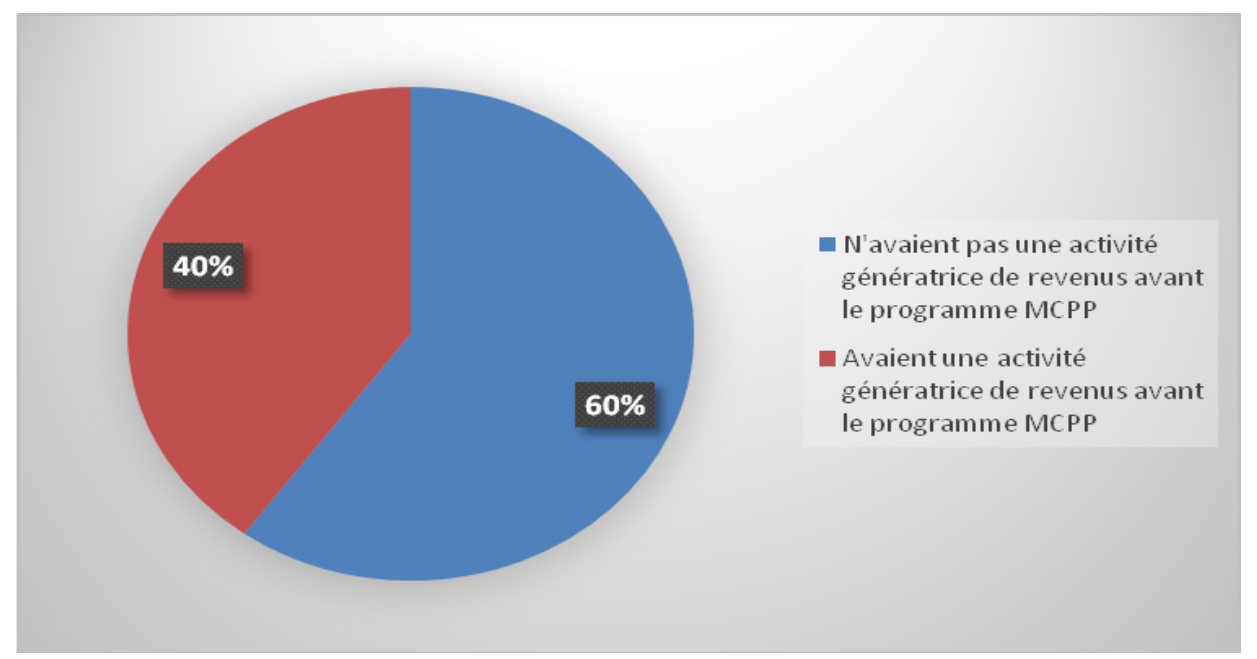

Figure 1: Economic situation of women before the MCPP program

Source: Field survey results, July 2018 
Before the implementation of the MCPP program, $40 \%$ of the women interviewed were engaged in an income-generating activity; the remaining $60 \%$ of the women were without an incomegenerating activity. They therefore lived at the expense of their husbands, who had to bring back the necessities for a modest meal. The minority of women (40\%) working in small retail outlets manage with a daily income that varies between 500 and 1,000 CFA francs. They carried out small activities with the help of parents, brothers and sometimes spouses. But most often these activities are temporary because the money received from relatives is often not large as needed.

The women stayed at home for domestic activities in accordance with tradition: "Gnonnu Xuessi" in the Fongbe language, understood "the woman of the house". They mainly took care of reproduction, education of children, cleaning of the house, preparation of the meal. Under these conditions, the husband's income is often insufficient to take care of the household expenses and poverty takes hold of households and especially women, due to the increase in expenses and the reduction in income. .

The advent of microfinance institutions as well as the gradual reduction of interest rates and the "facilitation" of the conditions of access to credit have enabled a large majority of women to seize the opportunity to engage in economic activities. in order to contribute alongside the spouses to reduce the shortage in households.

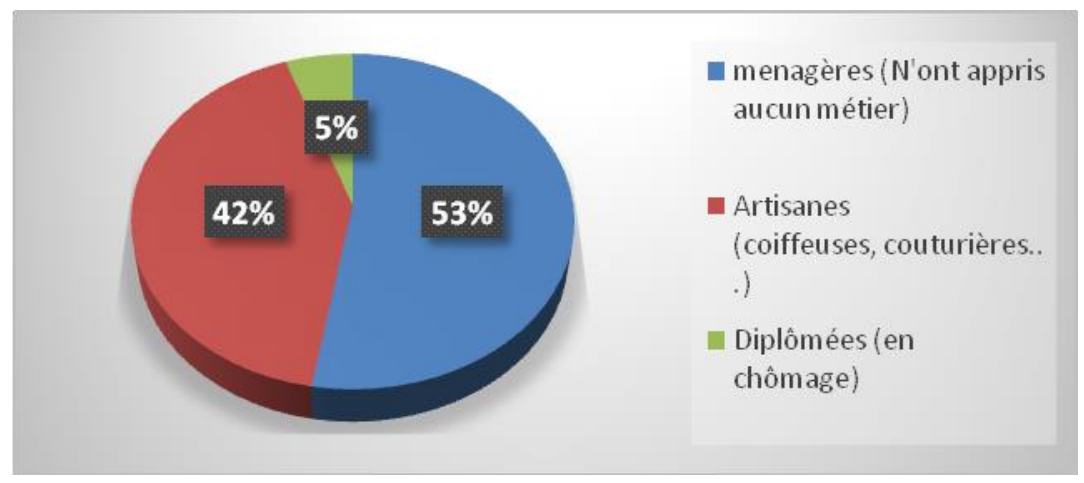

Figure 2: Occupation of women interviewed before the MCPP program

Source: Field survey results, July, 2018

The majority of women (53\%) interviewed have not learned a trade. They play the role of household managers. Those who do are those who have the support of their husbands and relatives to start small businesses. Also, $42 \%$ of these women have learned a trade but do not exercise it daily because of the lack of financial resources to give visibility to their activities. This means that purchasing power is generally very low and on average hovers around the poverty line of $\$ 1.90$ per day. As for the remaining $5 \%$ having a diploma, they find themselves in a situation of jobless. 
What is quite striking is that most women who receive credit through joint surety have no physical collateral. Solidarity microcredit consists of relying on a group mechanism generally composed of five borrowers in order to compensate for the lack of material guarantees from these individuals. Each acts as a "joint surety" for the others in the sense that if one of the members does not repay his loan, the others must do it for him. The risk of non-repayment is therefore transferred to the group itself. Although the loans are granted personally, the penalties for non-repayment concern the group. They are often in the form of suspension of new loans. Social pressure therefore causes each to reimburse because none wants to be the one penalizing the others, and they therefore have every interest in monitoring and excluding themselves those who are likely not to be able to repay: high-risk borrowers.

\subsection{Socioeconomic conditions of women after obtaining microcredits}

Microcredit institutions provide women with support services enabling them to have the capacity to manage income-generating activities. The amount of credit granted to women is capped at CFAF 30,000 for the first loan. Depending on the respect of the repayment deadline by the beneficiaries, they are allowed to benefit from CFA francs 50,000 for the second loan requested. These institutions also provide training in literacy and basic concepts in the management of Income Generating Activities, as well as on strategic savings which is made up of part of the amount of interest paid by beneficiaries on their loans. This savings is compulsory and will be returned to beneficiaries according to their repayment efforts.

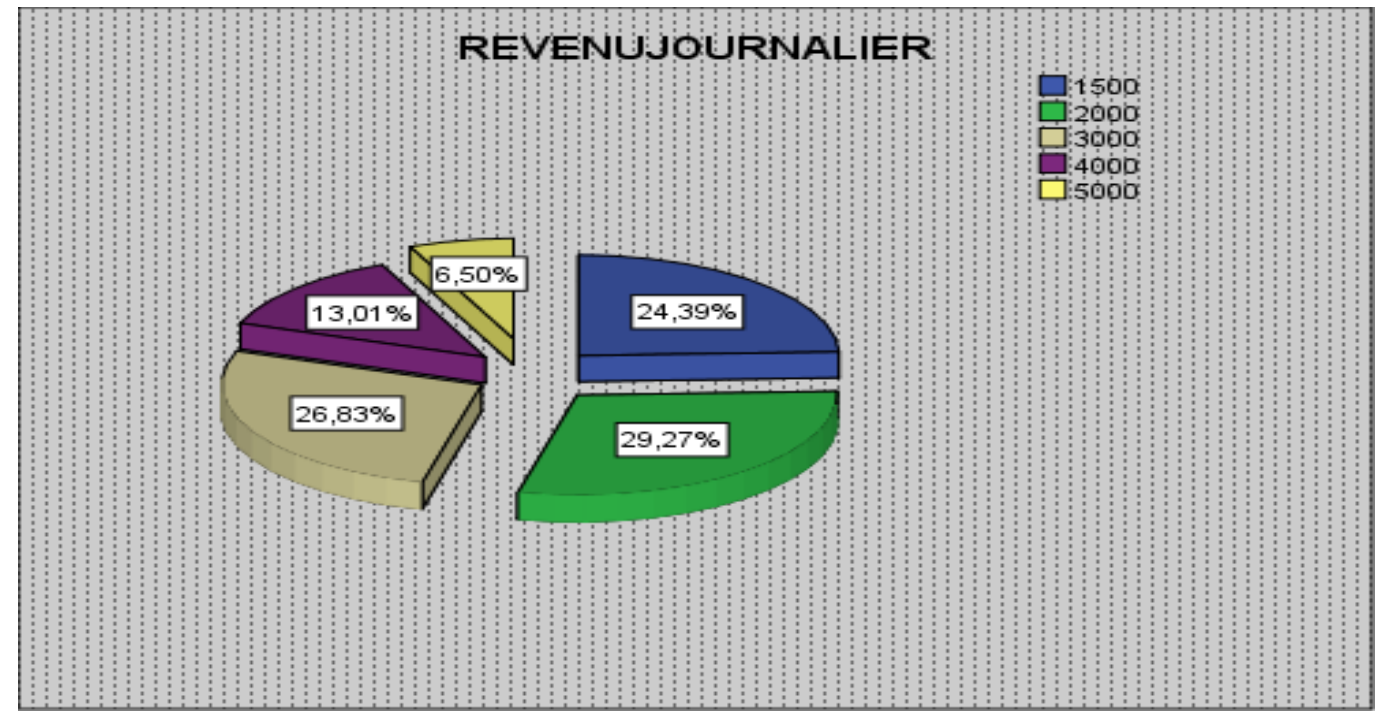

Figure 3: Daily income of women beneficiaries of loans from MFIs

Source: Field survey results, July, 2018

All the women we met appreciated the cost of this credit, because they made significant daily profits. Daily income varies from a minimum of 1,500 francs to a maximum of 5,000 CFA francs. This assumes that they are able to make a profit of at least 5,000 CFA francs per week and 20,000 CFA francs per month. 
However, $23 \%$ of the women interviewed expressed the wish that they will now be granted a deferral of at least one month regarding repayments. The observation is that over $17 \%$ of beneficiaries have difficulty repaying the loan on time. $60 \%$ of women manage to repay the credit but without this being used for reinvestment.In general, the women interviewed have a good impression of the microcredits granted by microcredit institutions, because for some, the income generated by these credits help them meet their basic needs (food, health, education of children, rent, electricity, water and clothing) and for others, apart from the satisfaction of basic needs, they manage to strengthen their income-generating activities. $82 \%$ of the women interviewed found the amount granted insufficient. They also specify that, thanks to the training that precedes and accompanies the granting of credit, the beneficiaries invest in different areas with the ultimate concern of repaying the capital and the interest on time while making a profit.

The women interviewed affirmed that microcredit has helped to increase their activities. The ratings given vary according to the level of satisfaction. In general, we note that microcredit was used by women to undertake activities and helped improve their living conditions.

However, the rise in the prices of goods and raw materials, due to the food and financial crises, contributes to increase the costs and therefore to reduce the profitability of women's activities. This state of affairs, added to the sluggish sales situation with which they are confronted, and also the difficulties experienced in regularly selling their products, are factors which slow down the development of the activities of the respondents.

\section{CONCLUSION}

In view of the results obtained, three levels of discussion emerge, namely, the vulnerable situation of Beninese women, the still difficult access to credit for MFIs and the improvement of living conditions.

The women we meet are in a situation where only the man takes care of the needs of all members of the family. Better still, others live in polygamy. And yet, the 8th arrondissement of Cotonou is a locality located in the heart of the economic capital of Benin. It emerges from all these elements that even in urban areas, socio-cultural constraints still persist in the daily realities of households. These results produced the same remark noted in the work carried out by Fourn (2011) who denounced the fact that the woman continues "... to fully play her reproductive role, she is made to stay at home. "Gnonnu Xuessi, Sunnu

Glégbénu ", an expression consecrated in an adage of the country to express the demarcation between the domestic, family and private sphere, which is the house and the public sphere reserved for men (Fourn, 2011, p.10). In the same perspective, Montcho (2018, page number?) Showed in her doctoral thesis how the Xwémènou women hold an impressive potential in entrepreneurship.

Microcredits are thus a means of promoting the empowerment of women to help them contribute to the care of the household. Swain (2007) previously highlighted the success of self-help bank linkage type microcredit programs in India and argued that these programs are increasingly being praised for their positive economic outcomes and for empowering women. Another study carried 
out in Algeria by Adjou and Aissou (2018) shows that 62.5\% of the women questioned had no activity. Women's access to credit has encouraged their occupation. As a result, $90.9 \%$ of the women beneficiaries experienced an improvement in their living conditions. The impacts were then felt on the education of children and the household diet. Vincent (2000), Ndiaye (2002) Pal (2009) also found that microcredit has brought about a change in the lives of beneficiaries, which implies that the more women have an income, the more they contribute to the well-being of the family. .

Despite these advantages, the process of accessing microcredit presents major constraints for women. First of all, you must have an identity card, then you must have savings and have a minimum of savings, but also you must be able to have a guarantee and have a "guarantor" ( endorser), and better the process of processing files is long and sometimes tedious. Kacem and Ghorbel Zouaril (2013) also found the same factors determining access to microcredit.

\section{REFERENCES}

Acclassato D., 2008, "Do the caps on microcredit rates in microfinance really serve the poor and small economic operators?” Developing Worlds, No. 141, pp. 93-109.

Acclassato D., 2010, "Microcredit between" institutional shopping "and targeting the poorest", Mondes en développement, No 152, pp. 31-34.

Adjou B. and Aïssou N., 2018, Study of the impact of microcredit in Algeria: Case "ANGEM BEJAIA", Master thesis in Economic Sciences, option Monetary and Banking Economy, University A. Mira de Bejaia, 125p.

Ahouansinkpo E.B.F., 2010, Women and poverty in urban areas and microfinance institutions: case of the AssEF (Association of mutual aid for women), University of Abomey-Calavi, Library of the Flash, $84 \mathrm{p}$

Alahanou E.D., 2010, Microcredit program for the poorest (PMCPP) in the process of poverty reduction in the ninth district of Cotonou, University of Abomey-Calavi, Bibliothèque de la Flash, $65 \mathrm{p}$.

Benicourt E., 2009, "Poverty according to the UNDP and the World Bank", Rural Studies 3 /, no 159-160, pp. 35-53.

DeslauriersJ. P., 1987, The methods of qualitative research, Quebec, The presses of the University of Quebec, $153 \mathrm{p}$.

Djade K., 2011, The informal economy in sub-Saharan Africa, Paris, L’Harmattan, 249 p.

National Microfinance Fund, 2009, Balance sheet and perspectives, Revue En Échos, 55 p.

National Microfinance Fund, 2011, Global Mission of the Microcredit Program to the Poorest (PMCPP), Study Report, Cotonou, 88 p. 
Grosjean P., 2000, "Amartya Sen's thought on development", Revue Quart Monde, no 176, p. 1 4.

Hofmann E. and Kamala M.G., 2003, "Microcredit for women, the miracle solution or Trojan horse of globalization?" in State of the debate Women's views on globalization: critical approaches to globalization, (dir. J. Bisilliat), Karthala, $17 \mathrm{p}$.

Honlonkou, A. N. et al, 2006, "Determinants of repayment performance in microfinance institutions in Benin", Annals of Public and Cooperative Economics, 72 (1), pp. 53-81.

INSAE, 2015, What to retain from the fourth general population and housing census, Cotonou, $47 \mathrm{p}$.

Kacem, S. and Ghorbel ZS, 2013, Analysis of the determinants of access to financial services of microcredit associations in rural Tunisia, http://www.erudite.univ-parisest.fr/evenements/colloques-et- conferences / atm-2013-communications-full-papers $/$ ? eID = dam_frontend_push \& docID $=25239,15 \mathrm{p}$.

Kounde D. Y., 2003, Microfinance products and the fight against poverty: the case of microfinance institutions (MFIs) in Benin, University of Abomey-Calavi, Bibliothèque de la Faseg, 72 p.

Ministry of Economy and Finance, 2007, Growth strategy for poverty reduction 2007-2009, Cotonou.

Ngabonzima, M.-G. I. 2009, The role of microfinance in the empowerment and active participation of women in local development in Rwanda, University of Quebec at Rimouski, 191 p.

UNDP / BENIN, 2007, In-depth diagnosis of the microfinance sector in Benin, Cotonou, $61 \mathrm{p}$. 